\title{
Utilization of Video Streaming as a Means of Online Learning for Indonesian Political Thinking Courses
}

\author{
Tamrin $^{1 *}$, Indah Adi Putri ${ }^{1}$, Mhd. Fajri ${ }^{1}$ \\ ${ }^{1}$ Department of Poltiical Science, Faculty of Social and Political Sciences, University of Andalas, Padang, Indonesia
}

*Corresponding author Email:: tamrin@soc.unand.ac.id

\begin{abstract}
There are two online learning goals; as the most effective means of achieving learning objectives and as an effective means of teaching and learning $(\mathrm{TnC})$, and as the most effective means of achieving learning goals more related to a form of flexibility that can encourage learning motivation. Whereas as the most effective means in the learning process is related to the ability of communication technology in providing learning facilities, such as social media. Choice towards technology is neutral, however the choice is determined by other dimensions related to the online learning process. This article explains social support factors in influencing the choice of communication media preferred by students at the University in the process of teaching and learning $(\mathrm{TnC})$ at Andalas University, Padang. From the results of a study using 190 surveys, it was found that the use of social media like Whatsapp was preferred rather than Ilearn provided by the University as a learning medium. Whatsapp as social media provides more social support for student interaction with learning material, student-teacher interaction and student-student interaction
\end{abstract}

\section{Keywords: Teaching and Learning Process, Online learning, Social Media}

\section{INTRODUCTION}

The success of achieving online learning goals is determined by social support factors in the formation of a learning community (19). The achievement of online learning goals is influenced by the meaning of interaction, if these interactions have meaning for each other in the formation of a learning community, the results of these interactions can support the goals of learning achievement (18). There is ease of communication between students and lecturers, as well as improving forms of cooperative learning between students and other students in the form of information sharing skills. Some of the advantages of online learning over conventional forms of learning include face-to-face learning; (1) there is ample time and opportunity for students to learn through the use of social media, and the use of social media as a form of supporting contribution in the learning process in Higher Education compared to the use of social media as a means of political change or supporting economic activities; (2)

This learning aims not to change the learning environment, but only to support the delivery of learning materials and tasks that can adapt to rapid behavior changes in an emergency. The use of communication technology in the teaching and learning
$(\mathrm{TnL})$ process is influenced by the use of costs incurred for technology costs. The social and economic background of society affects the use of communication technology as a teachin g and learning (TnL) tool (12), people from middle to upper economic backgrounds are more likely to use equipment communication technology compared to people who come from lower middle economic backgrounds. Social, age, educational, and economic background factors influence the form of PBM design and learning process using online networks, some of these factors determine orientation, attitudes, and knowledge about the use of communication technology in the PBM process through online networks.

\subsection{Related Works}

The term "distance emergency teaching" (ERT) is used in the teaching and learning process $(\mathrm{TnL})$ through the use of social media during the Covid-19 emergency response period, this term does not only contain the meaning of the process of 'teaching "and" learning "but also the meaning of" instructions " (14). There is a difference between online learning and distance emergency teaching (ERT), distance emergency teaching (ERT) is a pattern of changes to the learning system made during the emergency response period that 
is temporary in nature, as well as using the whole online learning method or blended learning as a temporary forms of learning until the emergency ends. to replace face-to-face learning (15)

Several other terms are related to this online learning process, including mobile learning, m-learning, media assisted learning, ubiquitous computing, mobile teaching technology, handheld learning and e-learning (11). There are differences in terms of technological innovation, such as differences in terms of mobility, mobile, learning, mobile learning is "all types of learning that occur in the environment and learning spaces that take into account the mobility of technology, the mobility of learners, and the mobility of learning" (12). There are several different uses of the term in using the internet as a means of teaching and learning (TnL) during the Covid-19 emergency response period, including distance learning, distributed learning, and learning (13). blended learning, online learning, mobile learning, and others.

There are several choices in each of these dimensions of online learning, there is no best form of online learning from several factors that must be considered in the online learning process. The best form is determined by the form of decisions taken in the learner's design. There is no similar term used in the online learning process. There is no exact term that describes the learning and teaching process using the internet. There is a political meaning of some of the terms used, such as the term "blended learning" which contains a political agenda to provide flexibility, in order to be able to implement policies that are in accordance with the educational environment in each university (10).

There are several user orientations in utilizing i-learning as a means of teaching and learning (TnL), some of these orientations encourage students to no longer use internet learning (I-Learn) as a means of TnL when GOALS (I-Learn) has provided access to interaction forums between lecturers and students through forums, available chat, use of social media as a means of interaction between lecturers and students in disseminating orientation status updates.

Where information is the orientation of $\mathrm{Y}$ generation students. prefer to use social media as a means of interaction in the teaching and learning process (TnL), the interaction between students and lecturers is disrupted when interactions in learning contain information dissemination (21) The use of social media is used as a means of disseminating information about the environment, this use increases in times of natural disasters (8). There are around 11,575,270,054 students worldwide who have been affected by the worldwide spread of the pandemic virus, 191 countries have implemented policies to close schools nationwide and 5 countries have implemented policies to close schools locally. All of these policies affect $91.3 \%$ of the world's student population (7). The use of social media as a means to accelerate the decision-making process in the event of a natural disaster, is also used as communication in the teaching and learning process in educational institutions (9)

\subsection{Our Contribution}

The implementation of the policy of using i-learning as a teaching and learning tool (PBM) has been carried out by Andalas University, Andalas University is an educational institution in the city of Padang which has implemented a Covid-19 precautionary policy since February 28, 2020 [10]. The Covid-19 non-natural disaster mitigation policy contains regulating the form of teaching and learning (TnL) from the form of faceto- face meetings to the use of online (online) networks, there is support from Andalas University in changing this TnL, including providing i-learn facilities (internet learning). Health environmental factors influence the formulation and implementation of these non-natural disaster mitigation policies, including the influence of the international ecological environment as an extrasocial environment as well as physical and biological environmental factors as a social environment for the spread of the Covid-19 virus.

Ilearn as a means of learning the internet has provided chat and class discussion features as a means of interaction between lecturers and students or students and students. The purpose of providing these features includes inculcating attitudes, values, and knowledge about ilearn, but also to overcome the psychological and social impacts of humans during the implementation of the Covid-19 non- natural disaster mitigation policy in higer education. The following article explains about making video streaming as a form of online learning, the assignment is given to Semester I students of the 2019/2020 Academic Year who are taking Indonesian Political Thought courses in the Department of Political Science, Faculty of Social and Political Sciences, Andalas University. This online learning activity is a form of implementation of the Rector's non-natural disaster mitigation policy Number 6/2020 dated March 16, 2020 at Andalas University

\subsection{Paper Structure}

The rest of the paper is organized as follows. Section 2 introduces the methods of this research, which includes the type of research and population samples. This research is a descriptive survey, the research subjects were respondents who had inclusion criteria. Based on some of these criteria, it was obtained 190 students who became respondents in this study. Then, data analysis 
was carried out through the use of quantitative descriptive analysis, in the form of the number or frequency of each research variable

\section{BACKGROUND}

This study aims to see students' perceptions of nonnatural disaster mitigation policies on vigilance of the spread of virtus Covid-19 in the Andalas University environment. This research is a descriptive survey (22). The study population was all students from the Department of Political Science, Faculty of Social and Political Sciences, Andalas University in Padang which is the best university outside Java for 2020. The research subjects were respondents who had inclusion criteria; on students' intelligence and concern for environmental policy issues can be explained from the achievement index and the number of courses taken. were $2.6 \%$, and 2 respondents $(0.4 \%)$ took 2 courses.

Furthermore, there are $76(40 \%)$ students in the 2019 class, $75(39.5 \%)$ students from the 2018 class, 38 students (38\%) from the 2017 class students, and 1 student $(0.5 \%)$ from the class year students. 2015. The students' socio-economic background comes from the middle class community, this research was conducted from February to May 2020. ) as a form of mitigating non-natural disasters from the spread of the Covid-19 virus. Data analysis was carried out through the use of quantitative descriptive analysis, in the form of the number or frequency of each research variable

\subsection{Youtube Video Streaming}

The online learning process is an effort to form a community that needs assistance with extra-curricular (co-curricular) learning materials and forms of social support. another. Students are not particularly happy about studying online for too long, there is a need for social relationships and other forms of additional curriculum to support them so that students can spend more time studying online. From the results of a survey conducted on 190 students, the percentage of students who prefer to study face-to-face (interpersonal) is $87.9 \%$ higher than the percentage of students who like to study online which is $12.1 \%$

Teaching and learning (TnL) is defined as a process of various information and social interactions that must be supported by other activities: co-curricular and other forms of social support. The need for social support in the PBM process can also be explained from students' perceptions of the need for online tuition, with $69.2 \%$ of respondents considering that online lectures are not really necessary. Meanwhile, only $18.1 \%$ needed online lectures after the Covid-19 emergency response, and those who thought they didn't need more were $12.6 \%$. students who study government studies and public policy, and have a high level of concern for the impact of government policies on public life. Meanwhile, the exclusive criteria; among them consist of students who come from different class and social and economic backgrounds

\subsection{Methods}

This research was conducted through a survey method, students who were selected to be respondents based on the criteria for the level of intelligence and the length of time spent studying in tertiary institutions. From the predetermined criteria, it was obtained 190 respondents consisting of $96.8 \%$ consisting of students who have an achievement index of more than 3 on a scale of 1-4. Meanwhile, the respondents who took 7 subjects

There are variations in the amount of time students spend learning through online networks, including; (55.8\%) used 2-6 hours / day, $19.5 \%$ used 4-6 hours / day, $4.2 \%$ used more than 6 hours / day, while $21 \%$ of respondents used less than 2 hours. hour / day.

Students prefer blended learning forms rather than completely online networks. Students prefer online usage patterns with a $25 \%-50 \%$ interface. The lack of communication between lecturers and students at TnL using learning is one of the reasons for explaining the lack of student interest in learning options as TnL media, and preferring to use Whatsapp media as a form of learning in online networks. Whatsapp social media has the ability as a means of sharing information, but also as a means to support interactions between students and lecturers as well as students and students. Students use ilearn as a means of student interaction with learning material in the early stages, but at the later stage at the information sharing stage, students prefer Whatsapp media.

There is a higher element of flexibility to adjust the time and place in the learning process using Whatsapp media compared to other media, but it has limitations in the form of assignment instructions given by lecturers to students. The high percentage of using Whatsapp as a teaching medium favored by lecturers and students is related to the asynchronous teaching process, there is flexibility between lecturers and students for the use of time. To overcome the limited space available as a means of interaction between lecturers and students, the University provides ilearn as a learning medium as an option favored by lecturers and students, although there is a difference in the percentage of choices for using ilearn as a learning medium preferred by lecturers $(28 \%)$ and the percentage choice favored by students ( 9 , $5 \%)$. 
Making video streaming is a learning tool that aims to increase student and lecturer interest in learning interest. The streaming video is uploaded to Youtube so that it can get public attention and expand the learning space from the classroom to a wider public space. Assessment of the form of cooperation and communication of group members is carried out in assigning the task of making video streaming which is uploaded to the internet via Youtube media. Students participating in this course are divided into several groups, each group consisting of 6-7 students who are determined according to the even or odd attendance number from the student attendance list. Each group has to work on a project that contains a video that must be uploaded to the internet via Youtube.

17, 2020, with 14 views; (5) 8 group videos uploaded since February 28, 202010 views, 1 subscriber. The response was given as a form of appreciation from the
There are provisions for the duties of the members of each group including being a host, as a technician who designs and designs shows that attract viewers to watch them, as well as a resource person who provides answers to questions from the host who is the host of the event. There was a public response to video shows produced by student collaboration on Soekarno's forms of political thought, including; (1) Group 1 video watched 32 times since 18 February 2020, 5 likes and 3 subscribers ; (2) group video 2 has been watched 49 times since February 18, 2020, 10 likes, and 6 subscribers ,; (3) group video 3 has been watched 46 times since February 20, 2020, 7 likes, and 5 subscribers; (4) group video 7 uploaded since February

audience for the students' innovation and creativity in packaging the show into a form of interesting and liked learning.

\section{Tabel 1 The response of the video streaming audience of Indonesian Political Thought subject"s students}

\begin{tabular}{|l|l|c|c|c|}
\hline \multicolumn{2}{|c|}{ Upload Date } & \multicolumn{3}{c|}{ Audience Response } \\
\cline { 3 - 5 } \multicolumn{2}{|l|}{} & Watched & Like & Subscribes \\
\hline Group I & 18 February 2020 & 32 & 5 & 3 \\
\hline Group II & 18 February 2020 & 49 & 10 & 6 \\
\hline Group III & 20 February 2020 & 46 & 7 & 5 \\
\hline Group VII & 17 February 2020 & 14 & 0 & 0 \\
\hline Group VIII & 28 February 2020 & 10 & 0 & 1 \\
\hline
\end{tabular}

The implementation of the learning process through the use of video streaming expands the space and time of the learning process from the form of faceto-face interpersonal communication between lecturers and students from limited space and time in the classroom to a wider and unlimited space and time, as well as the learning process from students to students as a form of independent campus learning. There is an increase in communication between students and students and between students and the public, besides that there is also an increase in new creations from the form of collaboration in making video streaming as a means of online learning.. It is hoped that these social and cultural changes can produce innovations that can be used as a means to become a professional Youtuber, and can generate economic benefits.

Some of these processes have been carried out through face-to-face learning and teaching, as was done in the Indonesian Political Thought course. The Indonesian Political Thought course as a compulsory major is followed by 46 students in the even semester of the 2019/2020 school year. The distribution of the value of the Indonesian Political Thought course in the previous semester was between 70 and $85(\mathrm{~B}+\mathrm{A})$. The learning progress of this subject has used Student Center Learning (SCL) with the Problem Based Learning (PBL) approach, as well as communicating with the teacher learning center approach ( TCL) on specific topics. In the learning process, primary materials are 
also used, such as books, journals, while the secondary materials used include power points, writing paper, audio-visual media and others.

The problem faced by many students in the second semester who took this course was the lack of knowledge and understanding of students about the meaning and concepts of political thinking, including due to the limited knowledge they had as a (initial)

semester 2 student. Some other problems are the limited ability of students' soft skills in developing lecture material in the form of interactions with humans or the surrounding community, this problem is influenced by, among other things, the background knowledge and experiences of previous students that vary from one another. The results of the Quality Control Team (GKM) survey conducted on students taking the Indonesian Political Thought course at the Department of Political Science explained that the majority (81.6\%) prefer Whatsapp as the most effective social media in online learning.

The use of Whatsapp as a learning tool can provide greater social support in the form of student interaction with lecturers and students with students and students, while using ilearn is only needed by students as a means of student interaction with learning materials. The task of making video streaming carried out by students in this course can increase the form of cooperation, and get

students with learning materials. The use of video streaming as a means of learning is the final process of other forms of learning process, there are several stages of the learning process that are passed before giving the task of making video streaming among them. (1) giving quiz assignments in the form of short questions on the learning material that has been taught after each class meeting, this assignment is a form of evaluation of the level of student understanding of the learning material that has been given; (2) class discussion in the form of group division, group division in this class discussion is carried out randomly based on the odd and even numbers in the student attendance numbers; (3) making video streaming based on group that are determined based on ther result of the assessment carried out in quiz assignments and group discussions, so that students can strengthen their understanding of learning materials that are rated low from the evaluation results on quiz assignments and previous class discussions through discussion of the same material in the discussion streaming video creation group The results of the assessment of quiz assignments and group discussions are the basis for membership in video streaming class discussions, the diversity of group members in each task strengthens the form of group social support from the audience who watched the video on Youtube.

There is an identification stage and a preparation stage in the process of making video streaming; (1) at the identification stage there is a student's role in the production process, starting from the role of technician, the role of the moderator and the role of the participant.The role of the technician is to play a role in managing the location and and the video editing process, while the role of the moderator is to guide class discussions about lecture material; (2) in the preparation stage there is preparation for mastery of the aspects of cognition, affection and psychomotor in the discussion of lecture material to convince the audience. This role already involves the skills taught in other subjects, such as public speaking, Indonesian and English;

(3) the implementation stage in the form of cooperation in one group, in order to produce impressions through the roles performed by each group member; (4) the editing stage which involves technical expertise, and involves knowledge obtained from Political Communication and Political Marketting courses.

The use of asynchronous learning methods in making video streaming not only increases forms of cooperation and social support in a group, but also involves the use of knowledge taught in other courses. The interdisciplinary nature of knowledge required in the task of making this streaming video supports student interaction with students, students and lecturers, and

member cooperation in class education. The diversity of assignment members in the quiz is based on the location of attending lectures, the lecturer assigns assignments to students to make a question that is submitted to other students to be answered. Furthermore, the same pattern was applied to other students. This collaboration in making questions and giving answers produces a form of explanation that becomes the basis for determining learning material for the next lecture session. There are questions given by lecturers to students, these questions must be answered by students as a form of quiz assignment. Furthermore,an assessment of the answers to the questions was given by other students

The function of the lecturer in the implementation of this quiz task is only as a coordinator, while the executive function carried out by students has changed the form of learning into a student learning center. This form of SCL is also carried out in the implementation of class discussion assignments, the form of group assignments is a class discussion that discusses certain topics in lectures that must be done together in 1 group, and presented in front of the class every week based on a mutually agreed sequence between students 
and students. lecturers (10\%). The placement of students as group members is based on the attendance list, as well as arranged according to the classification of attendance numbers consisting of odd and even numbers. Several documents must be filled in by students in carrying out class discussion activities, including form 1 containing a summary of the understanding of the material, form 2 containing the results of group discussions, form 3 containing group assessment sheets. The assessment of each form is carried out in secret, and submitted to the lecturer who was previously initialed by the head of each class discussion group, it is expected from the implementation of the class discussion assignments.

Although the assessment of this class discussion is carried out by each group member, there is a provision in filling out the group score sheet that there cannot be
3 equal assessments from group members regarding the participation of each other member in the group. Students' critical and analytical attitudes towards the form of member participation in class discussions can be developed through assignments to read learning materials provided by lecturers to students. Furthermore, the learning material is discussed in a group of 10 students.

The results of group discussion assessments and the implementation of Quiz assignments at each class meeting are the basis for implementing lecture material assignments that are discussed in video streaming activities, video streaming activities can cover the weaknesses of student interaction with learning material, student interaction with students and student interaction with lecturers.

\section{Table 2 Student Competency Levels in Tasks and Learning Media}

\begin{tabular}{|l|l|l|l|}
\hline & Quiz & Group discussion & Video Streaming \\
\hline Cognition & $\mathrm{X}$ & & \\
\hline Affection & & $\mathrm{XX}$ & \\
\hline Kinesthetic & & & $\mathrm{XXX}$ \\
\hline
\end{tabular}

\subsection{Online Learning}

The online learning process is not only a form of

information transmission, but also a form of social interaction and cognitive interaction. Not always the choice given in the implementation of effective teaching and learning (PBM), the effectiveness of the results achieved is determined by various considerations of the combination of dimensions of

online lectures. Literature reviews require more practice and feedback, but this method cannot be used in large classrooms. Even though the lecturer has tried to be optimal, the lecturer will not be able to get optimal feedback. Optimal results can only be obtained if each of these dimensions has a meaning of interaction, a more flexible asynchronous model is more suitable to be applied to the adult learning process.

There is a big difference between students and lecturers' interests in the use of Whatsapp social media and ilearn media as a form of online learning. The choice of
Whatsapp social media students as a means of online learning, not only as a means of various information. between students and lecturers, but also as a means of social interaction between students and students or students and their peer groups. The use of Whatsapp as a learning medium not only supports interaction between students and learning materials, but also students and students and students and lecturers through messages delivered in Whatsapp Gorup (WAG).

The use of Whatsapp is more widely used in subjects that use expository pedagogy rather than exploration forms, students need more explanation from lecturers or other students about learning material compared to subjects that use the form of exploratory pedagogy. The objective of effective learning in using online media is to enable student motivation to learn more through the use of more flexible learning media, such as Whatsapp social media. Whereas the purpose of using online networks as an effective way in the learning process is related to not allowing the use of face-to-face communication in the learning process, the goal of 
using online media as a learning tool places choices on the form of media used as neutral technology.

Economic factors put the choice of Skype media use lower than the use of the Zoom Ilearn application as a learning medium. The Skype application requires more time and special costs than Whatsapp or Zoom which can be obtained for free and involves many people, the cost factor determines the choice of using the application as a means of the online learning process. The data obtained from the survey results explained that $40 \%$ of these students spent between Rp. 50,000- Rp. 100,000 per month for online learning activities, while those above Rp. 200,000 only $6.8 \%$ of respondents. The background factor determines the form of using online learning communication technology. Students who come from good economic family backgrounds will spend more money on the online learning process than students from disadvantaged family backgrounds. This family economic background can be explained partly by spending on activities in the online learning process.

\section{CONCLUSION}

The factor of availability of social support determines the effectiveness of online learning in this way not only influenced by student interactions with learning materials, but also by student interactions with lecturers and students. These factors allow students to interact with learning materials as well as student interactions with lecturers and other fellow students. This tendency encourages students to prefer mixed learning forms which have a composition of $25 \%-50 \%$ using only online networks compared to fully online, as well as Whatsaap social media as a learning tool favored by students and lecturers The effectiveness of using the technology tools used is related to the dimensions of learning other online, such as pedagogy, the ratio of lecturers to students, the role of lecturers and students in online learning, the form of assessment given, and others

Good learning design is determined by the learning material and the choice of media available to support the learning process. The choice of this application is influenced by social and economic factors, social factors are the extent to which the choice of learning media provides social support for the learning process. While the economic factor is the extent to which the fees are used by students to use the learning media, the social support factor puts the choice of using Whatsapp social media preferred by students. Whatsapp can provide social support both in the form of student interaction with lecturers and student interaction with students, but it has limited abilities compared to ilearn which is more supportive of student interaction with learning material. The use of ilearn is only carried out by students when interacting with learning material at the initial stage of the lecture meeting, but the interaction is continued at the next meeting through the use of Whatsapap.

\section{ACKNOWLEDGMENT}

The author would like to thank the various parties who have helped fund this research, especially to the Ministry of Research, Technology and Higher Education through LP3M Andalas University who are willing to fund this research through the letter of agreement for the implementation of research on Development and Quality Assurance of Education (PPMP), Andalas University Fiscal Year Number T; 054 / UN.16.18 / PT.01.03 / 2020

\section{REFERENCES}

[1] Bochin M. Political System and The Infrastructure Equilibrium Of Its Functioning. ВІСНИК КНУТД. 2015;5(91):128-43.

[2] Easton D. An Approach to the Analysis of Political System. World Polit. 1957;9(3):383-400.

[3] Chilcote RH. Comparative inquiry in politics and political economy: Theories and issues. Comparative Inquiry in Politics and Political Economy: Theories and Issues. Oxford: Westview Press; 2018. p. 1-216.

[4] Easton D, GGunnell J, Graziano L. The Development of Political Science: A Comparative Survey. 2002. 275 p.

[5] Tamrin. Zulfadly A\& AZ. Planning For Participative Development Based On Local Values : Case Study of Kelurahan Lambuang Bukik , Padang. 2018. 2018;7(1):40-50.

[6] Report S. Coronavirus disease 2019 (COVID-19) Situation Report-72 HIGHLIGHTS. Vol. 2019. 2020.

[7] Setiawan AR. Scientific Literacy Worksheets for Distance Learning in the Topic of Coronavirus 2019. Read Acad Artic [Internet]. 2020;2(1):1-3. Available https://doi.org/10.1016/j.solener.2019.02.02 7\%0Ahttps://www.golder.com/insights/bloc kcaving-a-viable-alternative/\%0A???

[8] Chair S, Charrad M, Ben Saoud NB. Towards A Social Media-Based Framework for Disaster Communication. Procedia Comput Sci [Internet]. 2019;164:271-8. Available from: https://doi.org/10.1016/j.procs.2019.12.183

[9] Aljuboori AF, Fashakh AM, Bayat O. The impacts of social media on University students in Iraq. 
Egypt Informatics J [Internet]. 2020;(xxxx). Available from: https://doi.org/10.1016/j.eij.2019.12.003

[10] Czerniewicz L. What We Learnt from 'Going Online" during University Shutdowns in South Africa.' PhilOnEdTech. 2020;(March 15).

[11] Barbara Means, Marianne Bakia RM. Learning Online: What Research Tells Us about Wheter, When and How. New York: Routledge; 2014.

[12] Rossing JP, iller W, Cecil AK, Stamper S. iLearning: The Future of Higher Education? Student perceptions on learning with mobile tablets. J Scholarsh Teach Learn. 2012;12(2):1-26.

[13] Hodges C, Moore S, Lockee B, Trust T, Bond A. The Difference Between Emergency Remote Teaching and Online Learning. Educ Rev [Internet]. 2020;7. Available from: https://er.educause.edu/articles/2020/3/the-

difference-between-emergency-remote- teachingand-online-

learning?utm_source $=$ Newsletter+de+innov ación+educativa+\%28docentes\%29\&utm_c ampaign $=45 \mathrm{e} 0 \mathrm{a} 08 \mathrm{~d} 6 \mathrm{~b}-$

EMAIL_CAMPAIGN_2019_01_15_LDTE

C_COPY_01\&utm_medium=email\&utm

[14] Bentrovato LD and D. Understanding Education's Role in Fragility; Synthesis of Four Situational Analyses of Education and Fragility: Afghanistan, Bosnia and Herzegovina, Cambodia, Liberia. International Institute for Educational Planning. 2011.

[15] Aras Bozkurt, Ramesh Sharma. Emergency remote teaching in a time of global crisis due to CoronaVirus pandemic. Asian J Distance Educ. 2020;15(1):1-6.

[16] Thohari ANA, Satoto KI, Martono KT. Pembuatan Aplikasi Mobile Learning sebagai Sarana Pembelajaran di Lingkungan Universitas Diponegoro. J Teknol dan Sist Komput. 2013;1(2):56.

[17] Michael Sinkins, Karen Cole, Fern Tavalin BM. Increasing Student Learning Through Multimedia Projects. Alexandria: Association for supervision and Curricullum Development (ASCD) (; 2002. 55 p.

[18] Kuryanti, Sandra JK. Rancang Bangun Sistem ELearning sebagai Sarana Pemberlajaran Sandra. J Khatulistiwa Inform. 2016;4(1):84-92.

[19] Georgescu M, Popescul D. Social Media - The New Paradigm of Collaboration and Communication for Business Environment. Procedia Econ Financ [Internet].2015;20(2012):277-82. Available from: http://dx.doi.org/10.1016/S2212- 5671(15)00075-1
[20] Wehbe H, Bouabdallah A. A user-centric communication model for mobile web.Procedia Comput Sci [Internet]. 2012;10:680-7. Available from: http://dx.doi.org/10.1016/j.procs.2012.06.0 87

[21] Alwi NHM, Mahir NA, Ismail S. Infusing Social Media in Teaching and Learning (TnL) at Tertiary Institutions: A Case of Effective Communication in Universiti Sains Islam Malaysia (USIM). Procedia Soc Behav Sci [Internet].

2014;155(October):265-70. Available from: http://dx.doi.org/10.1016/j.sbspro.2014.10.2 90

[22] Zahtamal Z, Chandra F, Restila R, Restuastuti T. Defecation Behavior in Elementary School Age Children Who Live Along the Kampar River Riau Province. J Kesehat Lingkung. 2020;12(2):87. 